\title{
DAYA HAMBAT KAYU MANIS (Cinnamomum burmanni) TERHADAP PERTUMBUHAN BAKTERI KULTUR DARAH WIDAL POSITIF ANGGOTA FAMILIA Enterobacteriaceae
}

\author{
The Inhibition Of Cinnamom On Growth Of Bacterium On The Positive Widal Blood \\ Culture Of Enterobateriaceae Family Member
}

\author{
Windya Nazmatur Rahmah ${ }^{1 *}$ \\ *I,Fakultas Ilmu Kesehatan Universitas \\ Muhammadiyah Palangkaraya, Palangka \\ Raya, Indonesia \\ *email: windy.nazmatur@gmail.com
}

\begin{abstract}
Abstrak
Kayu manis memiliki aktifitas antibakteri yang tinggi, tetapi belum jelas efek antibakterinya terhadap bakteri kultur darah Widal positif anggota familia Enterobacteriaceae. Tujuan penelitian yaitu untuk mengetahui daya hambat kayu manis terhadap pertumbuhan bakteri kultur darah Widal positif anggota familia Enterobacteriaceae. Metode yang digunakan merupakan penelitian eksperimental dengan metode sumuran menggunakan sampel bakteri Salmonella typhi, Escherichia coli, Klebsiella pneumonia, Serratia marcescens, dan Enterobacter cloacae. Kayu manis sebagai larutan uji dengan konsentrasi $2 \%, 4 \%, 6 \%, 8 \%$, dan $10 \%$. Hasil penelitian menunjukan zona hambat mampu terbentuk pada media Nutrient Agar Plate (NAP) pada pertumbuhan bakteri familia Enterobacteriaceae, konsentrasi 10\% menunjukkan zona hambat rata-rata terbesar pada S. typhi, Ser. marcescens, E. cloacae, E. coli, Kleb. pneumonia berturut-turut dengan diameter yaitu $12 \mathrm{~mm}$, II mm, II mm, I0mm, dan $8,5 \mathrm{~mm}$, sedangkan konsentrasi kayu manis $8 \%, 6 \%, 4 \%$, dan $2 \%$ tidak mampu membentuk zona hambatan dalam 100 $\mu \mathrm{l}$ larutan uji dengan kloramfenikol sebagai kontrol positifnya.
\end{abstract}

Kata Kunci:

Kayu Manis

Widal

Enterobacteiaceae

Keywords:

Cinnamom

Widal

Enterobacteiaceae

\begin{abstract}
The cinnamom have a high activity of antibacterial, but the effect of the antibacteria toward the bacteria on the positive Widal blood culture of Enterobacteriaceae familia member was not clear yet.

The purpose of the this research was to find out the inhibition of cinnamom on growth of bacterium on the positive Widal blood culture of Enterobactriaceae family member. The method used in the research was an experimental research which was using draw well method and using Salmonella typhi, Escherichia coli, Klebsiella pneumonia, Serratia marcescens, and Enterobacter cloacae bacteria sample. Cinnamom as a test solution with a $2 \%, 4 \%, 6 \%, 8 \%$ and $10 \%$ concentrate. The research result was showed the inhibiting zone was able to form on the Nutrient Agar Plate (NAP) on growth of the Enterobacteriaceae, 10\% concentrate that high sensitive showed to S. typhi, Ser. marcescens, E. cloacae, E.coli, and Kleb. pneumonia squent was $12 \mathrm{~mm}, I I \mathrm{~mm}, I I \mathrm{~mm}, 10 \mathrm{~mm}$, and $8,5 \mathrm{~mm}$, while $8 \%, 6 \%$, $4 \%$, and $2 \%$ concentrate of cinnamom was unable perform of inhibition zone in $100 \mu$ l of test solution with a kloramfenikol as a positive control.
\end{abstract}

\section{PENDAHULUAN}

Demam tifoid tergolong dalam enteric fever yang berat dan bersifat sistemik sebagai akibat bakteremia yang terjadi dan menyebabkan kematian penduduk Indonesia untuk semua umur. Menurut WHO (2014) lebih dari 21 juta kasus deman tifoid menyerang pada anak yang berusia 3 -19 tahun, dan 200.000 diantaranya meninggal (Rachman, 20I I).

Diagnosis dari penyakit demam tifoid ini diperlukan pemeriksaan yang sering dilakukan seperti uji serologis yaitu pemeriksaan Widal. Uji Widal adalah salah satu metoda serologi dengan menggunakan sampel serum darah yang digunakan untuk membantu 
diagnosis demam tifoid karena dapat mengetahui adanya antibodi spesifik dalam serum penderita demam tifoid dengan cepat dengan hasil Widal positif yang ditandai bila terjadi aglutinasi (Sofyanita, 2015).

Demam tifoid merupakan penyakit yang dipengaruhi oleh lingkungan, perilaku hidup bersih dan sehat, hygiene diri yang didalamnya termasuk konsumsi jajanan sehat (Magfiroh \& Siwiendrayanti, 2016). Mengkonsumsi makanan yang tercemar bakteri, terutama serotipe Salmonella typhi yang termasuk bakteri anggota Enterobacteriaceae. Menurut penelitian Darmawati (20I2), pada kultur darah Widal positif diketemukan bakteri batang Gram negatif anggota familia Enterobacteriaceae yaitu: Enterobacter cloacae, S. typhi, Serratia marcescens, Escherichia coli, Salmonella sp., Klebsiella pneumoniae sp.

Tata laksana pengobatan pada demam tifoid yang terjadi karena bakteremia masih sering digunakan adalah istirahat, perawatan, diet, serta pemberian antibiotik. Namun Penggunaan antibiotik yang tidak rasional dapat menyebabkan resisten dimana bakteri akan memberikan perlawanan terhadap kerja antibotik dan juga dapat terjadi supra infeksi yang biasanya timbul pada penggunaan antibiotik spektrum luas dalam waktu yang lama, untuk mengatasi masalah resistensi antibiotik tersebut maka dapat dilakukan pengobatan alternatif dengan tanaman yang berkhasiat obat (Sujatmiko, 2014).

Salah satu tanaman yang berpotensi menjadi pengobatan alternatif adalah kayu manis yang memiliki kandungan minyak atsiri, safrole, sinamaldehida, tanin, dammar, kalsium oksalat, flavonoid, triterpenoid, dan saponin. Komponen minyak atsiri tersebut memiliki aktivitas sebagai antibakteri terhadap Escherichia coli dan Salmonella aureus (Puspita, 2014)

Berdasarkan latar belakang tersebut, mendorong peneliti untuk mengkaji tentang daya hambat kayu manis (Cinnamomum burmanni) terhadap pertumbuhan bakteri kultur darah Widal positif anggota familia Enterobacteriaceae.

\section{METODE PENELITIAN}

Penelitian yang dilakukan merupakan penelitian eksperimental. Metode sumuran menggunakan sampel bakteri Salmonella typhi, Escherichia coli, Klebsiella pneumonia, Serratia marcescens, dan Enterobacter cloacae. Kayu manis sebagai larutan uji dengan konsentrasi $2 \%, 4 \%, 6 \%, 8 \%$, dan $10 \%$ dengan 2 kali pengulangan. Kontrol positif yang digunakan adalah kloramfenikol yang ditanamkan pada media Nutrient Agar yang kemudian diinkubasi pada inkubator dengan suhu $37^{\circ} \mathrm{C}$ selama 24 jam.

\section{HASIL DAN PEMBAHASAN \\ HASIL}

Hasil penelitian daya hambat kayu manis terhadap pertumbuhan bakteri E. coli, S. typhi, Kleb. pneumonia, Ser. marcescens, dan E. cloacae pada media NA dengan menggunakan metode sumuran kemudian diinkubasi pada suhu $37^{\circ} \mathrm{C}$ selama 24 jam di peroleh hasil seperti berikut ini.

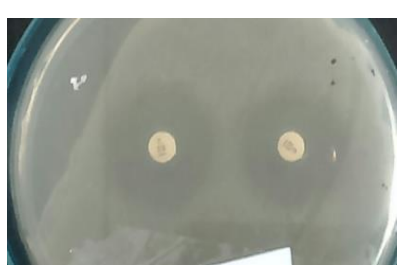

A

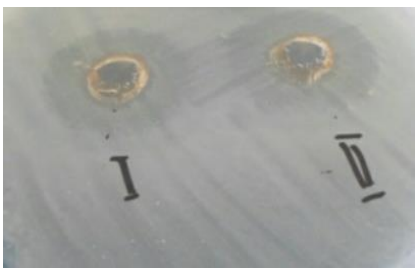

C

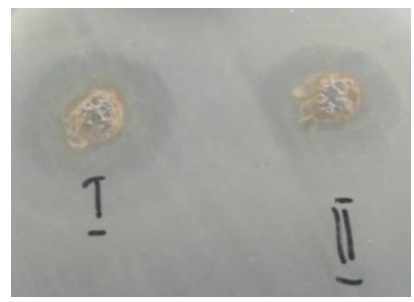

E

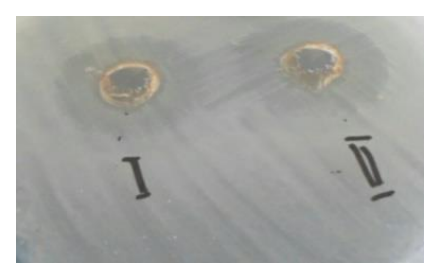

B

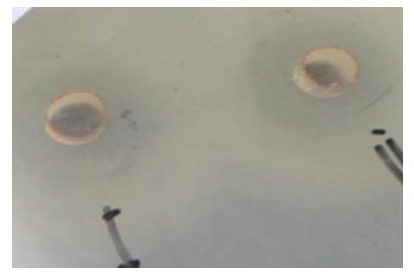

D

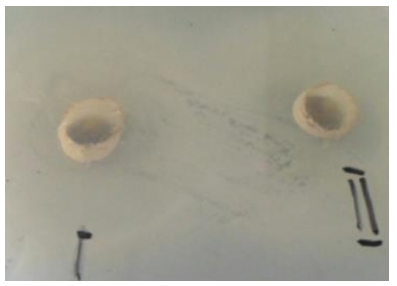

$\mathrm{F}$
Gambar I. (A) Kloramfenikol ; (B) S. typhi pada konsentrasi 10\% ; (C) E. cloacae pada konsentrasi 10\% ; (D) E.coli pada konsentrasi 10\% ; (E) Ser. marcescens pada konsentrasi I0\% ; (F) Kleb. pneumonia pada konsentrasi $10 \%$ 
Hasil infusa kayu manis terhadap pertumbuhan bakteri kultur darah Widal positif anggota familia Enterobacteriaceae pada metode sumuran dapat dilihat pada tabel berikut:

\begin{tabular}{|c|c|c|c|c|c|c|}
\hline \multirow[b]{2}{*}{ Bakteri } & \multicolumn{5}{|c|}{ Zona Hambat Kayu Manis (mm) } & \multirow[b]{2}{*}{$\mathbf{K}(+)$} \\
\hline & $2 \%$ & $4 \%$ & $6 \%$ & $8 \%$ & $10 \%$ & \\
\hline E. coli & - & - & - & - & 10 & 27 \\
\hline S. typhi & - & - & - & - & 12 & 26 \\
\hline $\begin{array}{l}\text { Kleb. } \\
\text { pneumonia }\end{array}$ & - & - & - & - & 8,5 & 26 \\
\hline $\begin{array}{l}\text { Ser. } \\
\text { mercescens }\end{array}$ & - & - & - & - & 11 & 27 \\
\hline E. cloacae & - & - & - & - & 11 & 28 \\
\hline
\end{tabular}

\section{PEMBAHASAN}

Data hasil infusa kayu manis dengan konsentrasi $2 \%, 4 \%$, $6 \%$, dan $8 \%$ dengan metode sumuran tidak mampu membentuk zona hambatan, namun pada konsentrasi $10 \%$ bakteri S. typhi mampu membentuk zona hambatan terbesar dengan diameter $12 \mathrm{~mm}$, serta hasil zona hambat yang terkecil terbentuk pada bakteri Kleb. pneumonia dengan diameter $8,5 \mathrm{~mm}$ yang mana kontrol positifnya menggunakan kloramfenikol dengan diameter $\geq 18$ $\mathrm{mm}$.

Aktivitas antibakteri dapat dipengaruhi oleh beberapa faktor yaitu konsentrasi ekstrak, daya difusi ekstrak, jumlah bakteri dan jenis bakteri. Zona bening yang terbentuk dipengaruhi oleh konsentrasi ekstrak yang tinggi (Maliana, 20I3).

Konsentrasi ekstrak kayu manis 10\% menunjukkan zona hambat rata-rata terbesar pada $S$. typhi, Ser. marcescens, E. cloacae, E. coli, Kleb. pneumonia berturut-turut dengan diameter yaitu $12 \mathrm{~mm}$, II mm, II mm, $10 \mathrm{~mm}$, dan $8,5 \mathrm{~mm}$, sedangkan konsentrasi kayu manis $8 \%, 6 \%, 4 \%$, dan $2 \%$ tidak mampu membentuk zona hambatan dengan kloramfenikol sebagai kontrol positifnya. Berdasarkan penilaian diameter zona hambatan dengan kontrol antibiotik kloramfenikol menurut Clinical and Laboratory Standards Institute (CLSI) sensitive apabila diameter zona hambatan $\geq 18 \mathrm{~mm}$ dan resisten apabila diameter zona hambatan $\leq 12 \mathrm{~mm}$.

Konsentrasi ekstrak semakin tinggi maka semakin besar besar zat antibakteri, sehingga kemampuannya semakin besar dalam menghambat pertumbuhan bakteri. Konsentrasi ekstrak kayu manis kurang dari 10\% termasuk dalam klasifikasi daya hambat lemah karena nilai rata-rata diameter zona hambat lemah $\leq 12 \mathrm{~mm}$.

Menurut Yunensa (2016) uji efektifitas kayu manis dengan antibiotik kloramfenikol dilakukan dengan metode difusi Kirby Bauer dimana penggunaan metode ini mempunyai keunggulan daripada metode lain, selain sampel yang digunakan lebih sedikit daripada metode sumuran, kemampuan zat antibakteri untuk menghambat pertumbuhan bakteri dapat diamati dengan mudah melalui diameter zona hambat yang dihasilkan, namum kandungan kayu manis dari larutan tersebut mempunyai viskositas yang tinggi maka penyerapan kandungan pada sumuran akan rendah, hal ini dapat menyebabkan difusi ekstrak tidak membentuk zona hambatan pada uji data hambat kayu manis yang berkonsentrasi rendah.

Daya hambat terbentuk disebabkan karena kayu manis mengandung minyak atsiri, tanin, sapoin, dan flavonoid yang mana kandungan-kandungan tersebut mempunyai efek antiseptik dan bekerja dengan merusak membran sel (Nugroho, 1015). Zona hambat pada bakteri anggota familia Enterobacteriacea yang termasuk dalam golongan bakteri gram negatif juga dipengaruhi struktur dinding sel bakteri yang mana pada dinding sel bakteri gram negatif terdiri dari beberapa lapisan peptidoglikan dan lipopolisakarida, oleh karena itu dinding selnya tidak mudah terdenaturasi oleh zat aktif sehingga diameter daya hambatnya lebih kecil daripada bakteri yang tergolong gram positif. Luasnya diameter zona hambat merupakan suatu petunjuk bahwa bakteri memiliki 
kepekaan terhadap senyawa atau zat antibakteri. Jenis bakteri Gram negatif ini juga di pengaruhi oleh struktur penyusun bakteri tersebut sehingga kepekaan terhadap senyewa antibakteri berbeda-beda, yang mana seperti bakteri S. typhi merupakan bakteri yang membentuk zona hambatan yang terbesar dari semua bakteri uji ini tidak berspora maupun berkapsul sehingga zat antibakteri dapat lebih efektif menembus membran sel untuk terdenaturasi, dan bakteri Kleb. pneumonia yang mempunyai kapsul yang dapat membentuk jaringan longgar berupa fibrin-fibrin yang meluas ke arah luar sel sehingga antibakteri yang konsentrasinya kecil hanya dapat membentuk zona hambatan yang kecil (Sofyanita, 2015).

Dapat diketahui bahwa kandungan zat antibakteri yang terdapat dalam kayu manis terbukti dapat menghambat pertumbuhan bakteri gram negatif dengan meningkatkan konsentrasi larutan uji.

\section{KESIMPULAN}

Berdasarkan hasil penelitian dapat diketahui bahwa kandungan zat antibakteri yang terkandung dalam ekstrak kayu manis (Cinnamomun burmanni) terbukti dapat menghambat pertumbuhan bakteri widal positif anggota familia Enterobacteriaceae.

\section{DAFTAR PUSTAKA}

Chandukar P, N Tripathi N, Choudary A, Murab T. Antibacterial properties of cinnamon stick oil with special reference to Streptococcus pyogenes and Pseudomonas aeruginosa. International Journal of Current Microbiology and Applied Sciences. 20। 4;3:177-8. 9

Darmawati, S., L. Sembiring, W. Asmara, W.T. Artama. 2012. Keanekaragamanan Spesies Bakteri Pada Kultur Darah Widal Positif Asal Kota Semarang Berdasarkan Karakter Fenotipik. Universitas Gadjah Mada. Yogjakarta.

Hermawan. A. 2007. Pengaruh Ekstrak Daun Sirih (Piper betle L) Terhadap Pertumbuhan Staphylococcus aureus dan Escherichia coli dengan Metode difusi Disc. Fakultas

\section{Kedokteran Hewan Universitas Airlangga. Surabaya}

Maliana. Y. 2013. Aktivitas Antibakteri Kulit Garcinia mangostana Linn. Terhadap

Pertumbuhan Flavobacterium dan

Enterobacter Dari Coptotermes curvignathus Holmgren. Fakultas Teknik Kimia

Universitas Tanjungpura. Pontianak.

Manoi, 2009, Binahong Sebagai Obat, WARTA Penelitian dan Pengembangan Tanaman Industri Volume 15 No. I Pusat

Penelitian dan Perkembangan Perkebunan, Yogyakarta

Rachman, F. A. 20II. Uji Diagnostik Tes Serologi Widal Dibandingkan Dengan Kultur Darah Sebagai Baku Emas Untuk Diagnosis Demam Tifoid Pada Anak Di RSUP Dr. Kariadi. Skripsi. Fakultas Kedokteran Universitas Diponegoro. Semarang.

Sujatmiko, Y. A. 20l4. Aktivitas Antibakteri Ekstrak Kayu Manis (Cinnamomum burmanni) dengan Cara Ekstraksi yang Berbeda Terhadap Escherichia coli Sensitif dan Multiresisten Antibiotik. Skripsi. Fakultas Keguruan dan Ilmu Pendidikan Universitas Muhammadiyah Surakarta. Surakarta

Susanto, Sudrajat D, Ruga R. Studi kandungan bahan aktif tumbuhan meranti merah (Shorea leprosula Miq) sebagai sumber senyawa antibakteri. Mulawarmnan Scientific. 2012;। I (2): I8I-90.

Sofyanita, E. N. 2015. Efektivitas Madu Hutan Dalam Menghambat Pertumbuhan Bakteri Pada Kultur Darah Widal Positif Anggota Familia Enterobacteriaceae.

Karya Tulis IImiah. Fakultas IImu Keperawatan dan Kesehatan Universitas Muhammadiyah Semarang. Semarang.

Yunensa, K. S. 2016. Pengaruh Kombinasi Antibiotik Ampisilin dan Minyak Atsiri Kulit Batang Kayu Manis (Cinnamomum burmanni) Terhadap Staphylococcus aureus Multiresisten. Fakultas Farmasi Universitas Muhammdiyah Surakarta. Surakarta. 